\title{
Characterization of Plant Seeds by Phosphorus-31 Nuclear Magnetic Resonance Spectroscopy
}

Ebuele, Victor Oghogho; Santoro, Anna; Thoss, Vera

\section{Analytical Chemistry Letters}

DOI:

$10.1080 / 00032719.2016 .1206910$

Published: 01/01/2017

Peer reviewed version

Cyswllt i'r cyhoeddiad / Link to publication

Dyfyniad o'r fersiwn a gyhoeddwyd / Citation for published version (APA):

Ebuele, V. O., Santoro, A., \& Thoss, V. (2017). Characterization of Plant Seeds by Phosphorus31 Nuclear Magnetic Resonance Spectroscopy. Analytical Chemistry Letters, 50(6), 999-1012. https://doi.org/10.1080/00032719.2016.1206910

\footnotetext{
Hawliau Cyffredinol / General rights

Copyright and moral rights for the publications made accessible in the public portal are retained by the authors and/or other copyright owners and it is a condition of accessing publications that users recognise and abide by the legal requirements associated with these rights.

- Users may download and print one copy of any publication from the public portal for the purpose of private study or research.

- You may not further distribute the material or use it for any profit-making activity or commercial gain

- You may freely distribute the URL identifying the publication in the public portal ?
}

Take down policy

If you believe that this document breaches copyright please contact us providing details, and we will remove access to the work immediately and investigate your claim. 


\section{Characterization of Plant Seeds by Phosphorus-31 Nuclear Magnetic Resonance Spectroscopy}

\section{Victor Oghogho Ebuele, Anna Santoro \& Vera Thoss}

To cite this article: Victor Oghogho Ebuele, Anna Santoro \& Vera Thoss (2016):

Characterization of Plant Seeds by Phosphorus-31 Nuclear Magnetic Resonance Spectroscopy, Analytical Letters, DOI: 10.1080/00032719.2016.1206910

To link to this article: http://dx.doi.org/10.1080/00032719.2016.1206910

Accepted author version posted online: 05

Aug 2016.

Published online: 05 Aug 2016.

Submit your article to this journal $\sqsubset$

Q View related articles $₫$

View Crossmark data \lceil 
Supertitle: Spectroscopy

\title{
Characterization of Plant Seeds by Phosphorus-31 Nuclear
}

\section{Magnetic Resonance Spectroscopy}

\author{
Victor Oghogho Ebuele \\ School of Chemistry, Bangor University, UK \\ Anna Santoro \\ School of Chemistry, Bangor University, UK \\ Vera Thoss* \\ School of Chemistry, Bangor University, UK \\ *Address correspondence to Vera Thoss. Tel: +44 (0)1248 382516. Fax: +44 (0)1248 370528 . E- \\ mail: v.thoss @bangor.ac.uk
}

Received 10 May 2016; accepted 24 June 2016.

\begin{abstract}
Plant seeds accumulate and store phosphorus for the initial growth of seedlings. Phosphorus speciation by 31P nuclear magnetic resonance (NMR) spectroscopy of NaOH-EDTA seed extracts showed that $\mathrm{P}$ was mainly present in organic forms such as phytate and $\alpha$ - and $\beta$ glycerophosphate in poppy, sesame, mustard, fennel, and cumin seeds. The inorganic P forms present included orthophosphate and pyrophosphate. The highest concentration of orthophosphate was found in $\mathrm{NaOH}-\mathrm{EDTA}$ extracts of fennel seeds (41.7\%) and the lowest in mustard $(9.3 \%)$ and sesame seeds $(6.9 \%)$. For the organic P forms, the highest concentration of phytate was found in mustard seeds $(85.2 \%)$ and the lowest in fennel seeds $(43.3 \%)$. Other organic P forms detected were $\alpha$ - and $\beta$-glycerophosphate ranging from $1.2 \%$ to $5.1 \%$ and $0.7 \%$
\end{abstract}


to $2.1 \%$, respectively. Pyrophosphate was detected in trace amounts only in fennel $(0.7 \%)$ and poppy seeds $(0.5 \%)$. The only orthophosphate diester observed was in sesame seeds at a low concentration $(0.7 \%)$, while phosphonates and polyphosphates were not present in any seeds. Phytate was the most dominant $\mathrm{P}$ form in all seeds except for fennel and cumin, which contained the lowest phytate concentration but the highest orthophosphate and glycerophosphate concentrations. These results suggest that $\mathrm{P}$ transferred from the plant vegetative parts to the developing seeds during maturation is converted to phytate (organic P) in addition to being stored as orthophosphate (inorganic P).

Keywords: ${ }^{31} \mathrm{P}$ nuclear magnetic resonance (NMR), phosphorus, phytate, seeds, speciation

\section{INTRODUCTION}

Phosphorus $(\mathrm{P})$ is an essential plant macronutrient that plays a central role in growth and metabolism. Plants require high amounts of $\mathrm{P}$ during its initial growing stage (germination) as the seed acts as a site for P storage (White and Veneklaas 2012). Phosphorus in seeds is mainly stored as phytate, also known as myo-inositol hexakisphosphate or phytic acid, which gradually builds up in seeds during maturation or ripening (Reddy 2002; Turner et al. 2002).

Phytate, a mixed salt of myo-inositol hexakisphosphate, also acts as a store of inositol phosphate and mineral cations in seeds (Lott et al. 2000). In seedlings, it helps in the formation of cell wall polysaccharides (Oberleas and Harland 1981; Dionisio, Holm, and Brinch-Pedersen 2007; Dionisio et al. 2011) and controls the orthophosphate equilibrium in seedlings and developing seeds (Lott, Greenwood, and Batten 1995). In addition, when phytate is released from seeds during germination, it is a major contributor of inorganic phosphate in the roots and shoots of the plant (White and Veneklaas 2012). Seeds containing a higher concentration of total $\mathrm{P}$ and phytate often show faster growth and development of seedlings, giving the plant rapid 
access to growth enhancing resources such as water and mineral elements and consequently producing plants with greater yields (Bolland and Baker 1988; Zhang, Nyborg, and McGill 1990; Ros, Bell, and White 1997). This accelerated growth is attributed to phytate hydrolysis, which rapidly remobilizes $P$ from seeds to seedlings (Nadeem et al. 2011).

The other main $\mathrm{P}$ forms present in plants is orthophosphate which may be present in different concentrations depending on the P availability during the plant's growth, plant species, and various environmental factors. Previous studies have shown that the concentration of orthophosphate in wheat may vary from $30 \%$ to $90 \%$ based on genotype and environmental factors such as soil fertility and seasonal conditions that include frost and drought. Crop management practices such as swathing or windrowing (chemical desiccation of the indeterminate crop, mainly used on grain crops like wheat and canola) may also prevent the translocation of $\mathrm{P}$ into the exported product and directly affect $\mathrm{P}$ cycling. Other practices such as the reduction of the $\mathrm{P}$ loading to grains in order to reduce its phytate concentration may also have an effect on P cycling and lead to an increase of inorganic P in crop residues (Batten 1992; Damon et al. 2014).

The orthophosphate concentration in plant tissues including seeds correlates with the supply from the parent plant (White and Hammond 2008). In general, orthophosphate constitutes about $60 \%$ to $80 \%$ of green plants during vegetative growth before seed formation, falling to $40 \%$ to $60 \%$ after seed formation and maturation (Damon et al. 2014). The regulation of metabolically active inorganic P concentration in the cytoplasm during plants' vegetative growth period is maintained by the vacuole where the excess inorganic P (mainly in the form of orthophosphate) is stored. These forms of inorganic P are highly water soluble and readily available for the growth and development of young seedlings, when released from crop residues. 
Studies of tobacco have shown that during high $\mathrm{P}$ availability, the concentration of inorganic $\mathrm{P}$ in leaves may be as high as $50 \%$ of total $\mathrm{P}$, while during periods of $\mathrm{P}$ deficiency, it may be as low as $20 \%$. As a result, inorganic $\mathrm{P}$ stored in the vacuole plays a significant role in the release of orthophosphate from crop residues to developing seedlings. The low levels of orthophosphate during the plant life cycle may also be a disadvantage for the growth and development of young seedlings due to reduced growth of roots and subsequent retarding of mineral resource acquisition (Damon et al. 2014).

Minor inorganic $\mathrm{P}$ species, pyrophosphates, and polyphosphates, have also been identified in the stems (Noack et al. 2012). Minor organic P species including cellular components deoxyribonucleic acid (DNA) and ribonucleic acid (RNA), have also been found in various concentrations depending on the plant species, climatic conditions, soil physiochemical properties, and phytoavailability of P in soil (Raboy et al. 2001; White and Veneklaas 2012). However, the identification and quantification of inorganic (orthophosphate, pyrophosphate, and polyphosphate) and especially of organic P forms (orthophosphate monoesters, diesters, and phosphonates) in plants may be difficult and limited by the available analytical techniques (Turner et al. 2005). ${ }^{31} \mathrm{P}$ nuclear magnetic resonance (NMR) spectroscopy is able to identify $\mathrm{P}$ species qualitatively and quantitatively (Cade-Menum and Preston 1996; Turner and Richardson 2004; White and Veneklaas 2012).

In this context, the present study is designed to elucidate the speciation and distribution of $\mathrm{P}$ species in cumin, fennel, flax, mustard, poppy, and sesame seeds with contrasting properties such as oil concentration and appearance (size and rigidity) using chemical characterization and ${ }^{31}$ P NMR spectroscopy.

\section{MATERIALS AND METHODS}




\section{Sample Preparation}

The plant seeds for this study were obtained from local stores (North Wales, United Kingdom) these include: cumin (Cuminum cyminum L.), fennel (Foeniculum vulgare Mill.), sesame (Sesamum indicum L.), mustard (Sinapis alba L.), poppy (Papaver somniferum L.) and flax (Linum usitatissimum L.) seeds. In the laboratory, the seeds were dried for 48 hours at room temperature $\left(20^{\circ} \mathrm{C}\right)$ and ground in a porcelain mortar to less than $2 \mathrm{~mm}$ particle size.

\section{Total and Inorganic phosphorus}

$0.5 \mathrm{~g}$ of sample $(n=3)$ was weighed and mixed with $5 \mathrm{~mL}$ of $70 \% \mathrm{HNO}_{3}$ (high purity grade, Sigma Aldrich) in an open borosilicate glass vial and left to stand for at least 12 hours. The mixture was then gently heated to $120{ }^{\circ} \mathrm{C}$ until complete dissolution of the sample was achieved. All acid extracts were diluted with deionized water to a final volume of $30 \mathrm{~mL}$, passed through ashless filter paper (Whatman No. 41), and stored at $4{ }^{\circ} \mathrm{C}$ until further analyses.

Water soluble inorganic P forms were extracted by using $0.5 \mathrm{~g}$ of seeds $(n=3)$ mixed with $25 \mathrm{~mL}$ of deionized water and shaken for one hour at room temperature. Samples were centrifuged at $5000 \mathrm{rpm}$, then passed through Whatman No. 41 filter paper and analyzed for P.

Phosphorus was measured in all extracts by using inductively coupled plasma atomic emission spectroscopy (ICP-AES) Varian 710ES (Agilent Technologies, USA) with axial view and equipped with a sample preparation system Varian SPS3 (Agilent Technologies, USA). The instrument parameters used were as follows: power: $1.2 \mathrm{~kW}$; plasma flow: $15 \mathrm{~L} \mathrm{~min}^{-1}$; auxiliary flow: $1.5 \mathrm{~L} \mathrm{~min}^{-1}$; nebulizer pressure: $240 \mathrm{kPa}$; pump rate: $15 \mathrm{rpm}$; and rinse time: $60 \mathrm{~s}$. Two wavelengths were selected for $\mathrm{P}(213.618 \mathrm{~nm}$ and $214.914 \mathrm{~nm})$ and an average of the concentrations obtained for the two wavelengths was used. A five-point calibration curve was employed for the analysis and the standards were prepared daily using a $1000 \mathrm{mg} \mathrm{L}^{-1}$ certified P 
standard solution (Fluka TraCert, USA). The instrument method detection limit $(\mathrm{MDL})=\mathrm{t}_{99 \%} \sigma / \mathrm{b}$ (where $t_{99 \%}$ is the t-student value at $99 \%$ confidence interval, $\sigma$ is the standard deviation of minimum 10 blank measurements and $b$ is the intercept, U.S. EPA 1994) was determined to be $0.03 \mathrm{mg} \mathrm{L}^{-1}$.

Two reference materials, WEPAL IPE-103 banana seeds (Wageningen University, The Netherlands) and BCR129 hay powder (IRMM, Belgium), were used for the validation of the method for total P content. Reference materials were digested in triplicate and measured with the seed samples. The results obtained were well within the acceptable values, being $1.770 \pm 0.218 \mathrm{~g} \mathrm{~kg}^{-1} \quad$ (Average $\pm 2 * \mathrm{SD}, \quad n=3$ ) for WEPAL IPE-103 (certified value $1.662 \pm 0.035 \mathrm{~g} \mathrm{~kg}^{-1}$ ) and $2.36 \pm 0.14 \mathrm{~g} \mathrm{~kg}^{-1}$ (Average $\pm 2 * \mathrm{SD}, n=3$ ) for BCR-129 (certified value $\left.2.27 \pm 0.01 \mathrm{~g} \mathrm{~kg}^{-1}\right)$.

The total carbon $(\mathrm{C})$ and nitrogen $(\mathrm{N})$ concentrations were determined using an automated solid sample total $\mathrm{C}$ and $\mathrm{N}$ analyzer (Leco Instruments, Truspec, USA). Approximately $0.1 \mathrm{~g}$ of plant sample was encapsulated in tin foil cups and to $950{ }^{\circ} \mathrm{C}$ combustion. EDTA was used as standard.

The concentrations of plant macro- and micronutrients for calcium, copper, iron, potassium, magnesium, manganese, sodium, sulfur, and zinc were quantified in the nitric acid extracts. The wavelengths for ICP-AES analyses were $\mathrm{Ca}(396.847 \mathrm{~nm}), \mathrm{Cu}(327.395 \mathrm{~nm}), \mathrm{Fe}$ $(238.204 \mathrm{~nm}), \mathrm{K}(766.491 \mathrm{~nm}), \mathrm{Mg}(279.553 \mathrm{~nm}), \mathrm{Mn}(257.610 \mathrm{~nm}), \mathrm{Na}(589.592 \mathrm{~nm}), \mathrm{S}$ (181.972 nm), and $\mathrm{Zn}(213.857 \mathrm{~nm}$ and $334.502 \mathrm{~nm})$.

\section{NaOH-EDTA Extraction}

The sample preparation for solution ${ }^{31} \mathrm{P}$ NMR spectroscopy was performed using a modified version of the Cade-Menun and Preston (1996) procedure developed originally for soil 
extraction. $1 \mathrm{~g}$ of crushed freeze-dried seed sample was mixed with $25 \mathrm{~mL}$ of a solution of $0.25 \mathrm{M} \mathrm{NaOH}$ and $0.05 \mathrm{M} \mathrm{EDTA}$ and shaken at $250 \mathrm{rpm}$ at $20{ }^{\circ} \mathrm{C}$ for 4 hours. The extracts were centrifuged for 20 minutes at $5000 \mathrm{rpm}$ and passed through Whatman No. 42 filter paper. An $0.5 \mathrm{~mL}$ aliquot was diluted for ICP-AES and the remaining solution was freeze-dried. The efficiency of $\mathrm{NaOH}-\mathrm{EDTA} \mathrm{P}$ extraction had a mean value of $94 \%$ for all samples (individual data are given in Table 1).

Approximately $100 \mathrm{mg}$ of each freeze dried extract was redissolved in $1 \mathrm{~mL}$ of $\mathrm{D}_{2} \mathrm{O}$, $0.1 \mathrm{~mL} 10 \mathrm{M} \mathrm{NaOH}$, and $0.6 \mathrm{~mL}$ extracting solution $(0.25 \mathrm{M} \mathrm{NaOH}+0.05 \mathrm{M}$ EDTA). Samples were centrifuged for 40 minutes at $5000 \mathrm{rpm}$ to remove particles that might contribute to line broadening and transferred to a $5 \mathrm{~mm}$ NMR tube and analysed via ${ }^{31} \mathrm{P}$ NMR.

\section{Characterization of Phosphorus Species by ${ }^{31}$ P NMR}

Spectra were acquired on a Bruker Advance DRX $400 \mathrm{MHz}$ NMR spectrometer (7.5T, 161.9 MHz), equipped with a $5 \mathrm{~mm}$ broadband probe at $20^{\circ} \mathrm{C}$. Instrument parameters were a $90^{\circ}$ pulse, $0.68 \mathrm{~s}$ acquisition time, and recovery delay of $4.32 \mathrm{~s}$ to $15 \mathrm{~s}$. Inverse gated proton decoupling (waltz 16) was used and set to at least five times the $\mathrm{T}_{1}$ (lattice relaxation time) based on the $\mathrm{P} /(\mathrm{Fe}+\mathrm{Mn})$ mass ratios. Between 1000 and 2500 scans ( $1-2$ hours running time) of the samples were required to achieve a good signal-to-noise ratio. The spectral width was $8090.6 \mathrm{~Hz}$ and the number of data points was 11002 .

The chemical shift (ppm) of the signals was indirectly referenced to an external $85 \%$ $\mathrm{H}_{3} \mathrm{PO}_{4}$ standard via the lock signal. Peaks were defined by three parameters: the chemical shift, line width and peak height. Peak assignment was based on plant extracts fortified with standard solutions and compared to the literature (Turner and Richardson 2004; Makarov et al. 2005; McDowell et al. 2005; Smernik and Dougherty 2007; Doolette, Smernik, and Dougherty 2009; 
Noack et al. 2012). Fortified solutions were used for the identification of phytate and $\alpha$ - and $\beta$ glycerophosphate. The extracts were fortified either with $0.1 \mathrm{~mL}$ of a $2.1 \mathrm{~g} \mathrm{~L}^{-1}$ aqueous phytate (Na salt hydrate from rice, Sigma Aldrich P8810) or with $0.1 \mathrm{~mL}$ of $4.0 \mathrm{~g} \mathrm{~L}^{-1}$ aqueous solutions of (1:1) $\alpha$ - and $\beta$-glycerophosphate disodium salt hydrate (Sigma Aldrich G6501).

The integration of peak areas was performed on spectra processed with line broadening from 1 to $2 \mathrm{~Hz}$ using a Bruker Topspin 2.0 software and MestReNova v.6.0. Quantification of $\mathrm{P}$ species was done by spectra deconvolution analysis, which proved to be successful for the monoester region containing a number of peaks, sometimes overlapping. The relative $\mathrm{P}$ concentration in the NaOH-EDTA extracts was estimated based on the total NMR signal area and presented as the percentage of each species. The chemical shift of the corresponding resonances varied only slightly between the samples as reported by Smernik and Dougherty (2007) and Makarov (2005). The largest variation in chemical shift was from the orthophosphate resonance from 5.46 to $5.73 \mathrm{ppm}$.

\section{RESULTS}

\section{Total Phosphorus and Elemental Analysis}

The results for total and inorganic $\mathrm{P}$ are presented in Table $\mathbf{1}$ with the percentages of total carbon and nitrogen. The total $\mathrm{P}$ in the seed samples varied from 4.5 to $8.3 \mathrm{~g} \mathrm{~kg}^{-1}$, with lower values for cumin, fennel, and flax seeds and higher values for mustard, poppy, and sesame seeds. The data for water extractable inorganic P were similar for all seeds, ranging from 21 to $32 \%$, with the exception of fennel for which the inorganic fraction accounted for almost $50 \%$ of the total P. Carbon and nitrogen were approximately 53 to $66 \%$ and 3 to $5 \%$ of the total mass.

The elemental composition of the seeds is shown in Table 1. Macronutrients such as $\mathrm{Ca}$

and $\mathrm{K}$ were highest in poppy and fennel seeds $\left(4.5 \mathrm{~g} \mathrm{~kg}^{-1}\right.$ and $\left.6.2 \mathrm{~g} \mathrm{~kg}^{-1}\right)$ and $\left(4.2 \mathrm{~g} \mathrm{~kg}^{-1}\right.$ and 
$\left.13.1 \mathrm{~g} \mathrm{~kg}^{-1}\right)$, respectively, and were lowest in sesame seeds $\left(1.0 \mathrm{~g} \mathrm{~kg}^{-1}\right.$ and $\left.3.7 \mathrm{~g} \mathrm{~kg}^{-1}\right) . \mathrm{Mg}$ was highest in poppy and sesame seeds, with both giving a concentration of $2.4 \mathrm{~g} \mathrm{~kg}^{-1}$. Other elements, such as $\mathrm{Na}$, were highest in fennel seeds $\left(2.7 \mathrm{~g} \mathrm{~kg}^{-1}\right)$, while $\mathrm{S}$ was highest in mustard seeds $\left(13.3 \mathrm{~g} \mathrm{~kg}^{-1}\right)$. Regarding the micronutrients, Fe was the highest in poppy $\left(135 \mathrm{mg} \mathrm{kg}^{-1}\right)$ and the lowest in flax $\left(68 \mathrm{mg} \mathrm{kg}^{-1}\right)$ seeds, while $\mathrm{Cu}$ was the highest in sesame seeds $\left(20 \mathrm{mg} \mathrm{kg}^{-1}\right)$ and lowest in mustard seed $\left(8 \mathrm{mg} \mathrm{kg}^{-1}\right)$. Other micronutrients such as $\mathrm{Zn}$ and $\mathrm{Mn}$ were the highest in poppy seeds $\left(61.3 \mathrm{mg} \mathrm{kg}^{-1}\right.$ and $\left.107 \mathrm{mg} \mathrm{kg}^{-1}\right)$ and lowest in flax seeds $\left(37 \mathrm{mg} \mathrm{kg}^{-1}\right.$ and $25 \mathrm{mg} \mathrm{kg}^{-}$ ${ }^{1}$ ), respectively.

\section{Phosphorus Species in the NaOH-EDTA Extracts}

The total P concentrations in the NaOH-EDTA seed extracts are shown in Table 1. In line with results obtained by Noack et al. (2012), most seed samples reported an extraction efficiency ranging from 75 to $110 \%$, with cumin seed giving the lowest efficiency. However, the relatively high efficiency showed by almost all the seeds in this study suggests that the $\mathrm{NaOH}$ EDTA extractant was able to access most $\mathrm{P}$ in the seeds.

Figure 1 shows ${ }^{31} \mathrm{P}$ NMR spectra of the $\mathrm{P}$ species found in the $\mathrm{NaOH}-$ EDTA seed extracts. All seeds showed peaks between 5.5 and $5.7 \mathrm{ppm}$, characteristic resonances for orthophosphate. The other inorganic $\mathrm{P}$ species detected was pyrophosphate at $-4.5 \mathrm{ppm}$, identified only in fennel and poppy seeds.

The organic orthophosphate monoesters showed resonances from 2.9 to $5.6 \mathrm{ppm}$ (Figure 1, inset) and orthophosphate diesters gave chemical shifts from -1.5 to $2.5 \mathrm{ppm}$. myo-Inositol hexakisphosphate (phytate) was identified at 5.2, 4.2, 3.8, and $3.7 \mathrm{ppm}$ (Figure 1, inset peak A) (Turner et al. 2002). The phytate peaks were confirmed after fortifying a NaOH-EDTA fennel seed extract with a phytate standard (Figure 2). The signals occurred in a ratio of 1:2:2:1, 
corresponding to the phosphate ion group on the inositol ring. Figure 2 also shows the results of fortification with $\alpha$ - and $\beta$-glycerophosphate. A 1:1 $\alpha$ - and $\beta$-glycerophosphate standard was added to a $\mathrm{NaOH}-E D T A$ cumin seed extract and an increase in intensity at $4.46 \mathrm{ppm}$ and 4.13 ppm was observed (Figure 2, inset peak B and C) compared to the original extract. Other resonances in the monoester region, occurring between 2.9 and $5.6 \mathrm{ppm}$, were attributed to lower inositol phosphates, sugar phosphates, and mononucleotides (Figure 1). The only diester P compounds present in sesame seed extract between 1.0 to $2.0 \mathrm{ppm}$ at low resonance intensities were attributed to non-hydrolyzed DNA and phospholipid compounds (Turner et al. 2002; Makarov et al. 2005)

\section{Phosphorus Species Quantification}

The $\mathrm{P}$ species found in the $\mathrm{NaOH}-\mathrm{EDTA}$ seed extracts are listed in Table $2 .{ }^{31} \mathrm{P}$ NMR spectra showed the presence of orthophosphate, pyrophosphate, phosphate monoesters, and diesters, while phosphonates and polyphosphates were not detected in any $\mathrm{NaOH}$-EDTA seed extracts. Phosphorous in seeds was predominantly organically bound as phytate as the major P containing species in all seeds from 75 to $94 \%$ with respect to total extractable organic P (Table 2). The highest relative percentage of $P$ as phytate was found in mustard seeds $(85.2 \%$ of total $\mathrm{NaOH}-\mathrm{EDTA}$ extractable P) and the lowest percentage was found in fennel seeds (43.3\% of total $\mathrm{NaOH}$-EDTA extractable $\mathrm{P}$ ). Other organic $\mathrm{P}$ species included degradation products, $\alpha$ - and $\beta$-glycerophosphate (most likely originated from phospholipid usually found in seeds), and mononucleotides (likely from nucleic material found in the seeds).

The proportion of $\alpha$ - and $\beta$-glycerophosphate ranged from $1.2 \%$ to $5.1 \%$ and $0.7 \%$ to $2.1 \%$ of the total $\mathrm{NaOH}-E D T A$ extractable P (Table 2). The sum of $\alpha$ - and $\beta$-glycerophosphate as the total glycerophosphate accounted for $6.8 \%$, of total $\mathrm{NaOH}$-EDTA extractable $\mathrm{P}$ in fennel, 
6.4\% in cumin, $5.2 \%$ in flax, $4.1 \%$ in sesame, $3.1 \%$ in mustard, and $2.6 \%$ in poppy seeds (Figure 3). The only orthophosphate diester detected was in sesame seeds at a low percentage $(0.7 \%$ of total $\mathrm{NaOH}$-EDTA extractable $\mathrm{P}$ ). The second most abundant $\mathrm{P}$ species was inorganic orthophosphate. In particular, the highest percentage of orthophosphate was found in fennel seed (41.7\% related to total NaOH-EDTA extractable P), while the lowest was in mustard (9.3\% of total NaOH-EDTA extractable P) and sesame seeds (6.9\% of total NaOH-EDTA extractable P).

Pyrophosphate was detected in trace amounts only in fennel ( $0.7 \%$ of total NaOH-EDTA extractable $\mathrm{P})$ and poppy seeds $(0.5 \%$ of total $\mathrm{NaOH}$-EDTA extractable $\mathrm{P})$. Table 1 shows the relative percentage of total extractable inorganic and organic $\mathrm{P}$ based on total NMR area. The values for the total extractable inorganic $\mathrm{P}$ determined by ${ }^{31} \mathrm{P}$ NMR were mostly comparable with the values obtained by chemical characterization (water extraction) and ICP-AES for inorganic water extractable P. In particular, the total extractable inorganic P in fennel, cumin, flax, and poppy seeds as determined by ${ }^{31} \mathrm{P}$ NMR provided percentages of $42 \%, 31 \%, 23 \%$, and $27 \%$ of total NaOH-EDTA extractable P, while chemical characterization (total water extractable inorganic P) gave values from $40-52 \%, 23-26 \%, 28-31 \%$, and $22-23 \%$, respectively. The oil seeds from mustard and sesame were the least comparable, giving a total extractable inorganic $\mathrm{P}$ of $9.3 \%$ and $7.2 \%$, compared to total water extractable inorganic $\mathrm{P}$ which were between 21 and $32 \%$ and 29 to $32 \%$, respectively.

\section{DISCUSSION}

Carbon, nitrogen, and phosphorus are essential elements for plants and are found in seeds at higher concentrations compared to the rest of the plant (Güsewell, 2004). Studies have shown that the vegetative parts of plants contain higher $\mathrm{N}$ to $\mathrm{P}$ ratios, compared to seeds, which have higher $\mathrm{N}$ and $\mathrm{P}$ concentrations but lower $\mathrm{N}$ to $\mathrm{P}$ ratios. Table 1 shows that the $\mathrm{N}$ to $\mathrm{P}$ ratio was 
below than eight for all seeds which was within the range of 1.5 to 15 reported for seeds from wild herbaceous plants (Güsewell, 2004). Table 1 also shows that poppy seeds, with the highest total $\mathrm{P}$ concentration, also had the lowest $\mathrm{N}$ to $\mathrm{P}$ ratio. These results suggest that $\mathrm{P}$ limitation during seed maturation, would likely affect biomass production and seed germination rates.

The recovery of $\mathrm{P}$ species from cumin and fennel seeds was low compared to from mustard, sesame, flax and poppy, although the total P concentration of cumin was observed to be the lowest. A possible explanation could be related to the difference in the seed's physical structure that may have affected the available surface area leading to poor $\mathrm{P}$ extractability in some seeds. The shorter extraction time used for this study may also have contributed to the lower recoveries. The extraction time prior to ${ }^{31} \mathrm{P}$ NMR is, however, a compromise between extraction efficiency, and the likelihood of deesterification occurring in the alkaline extraction medium. A short extraction time is usually recommended in order to prevent the loss and hydrolysis of labile P species, such as diesters (McDowell, Cade-Menun, and Stewart 2007) and may affect the final recovery. Another possible explanation is the high levels of macronutrients, $\mathrm{K}^{+}, \mathrm{Mg}^{2+}, \mathrm{Ca}^{2+}$ cations in the cumin seeds, which could have affected the extractability. These cations and other micronutrients such as $\mathrm{Mn}, \mathrm{Fe}$ and $\mathrm{Zn}$ are known to form mixed salts with phytate in seeds (White and Veneklaas 2012).

$\mathrm{Ca}$ and $\mathrm{K}$, which are related to biomass production and plant physiological processes such as cell structure, metabolic process and enzymes reactions, were shown to accumulate more in fennel and cumin seeds compared to the others. Of note was the particularly high concentration of $\mathrm{Ca}$ and $\mathrm{K}$ in fennel seeds. $\mathrm{Mg}$, on the other hand, which plays a major role during photosynthesis in plants (Coruzzi and Bushi 2001), was within the same range in all seeds, suggesting equal accummulation of $\mathrm{Mg}$ in all seeds. Sulfur, which is essential for the 
formation of proteins, was found to accumulate more in mustard seeds compared to the others. However, the high level of $\mathrm{S}$ in seeds may be as a result of its high allylisothiocynatye concentration, which is responsible for giving mustard seeds their characteristics pungent flavor (Pruthi 1999).

Overall, the P species detected in the seed extracts were similar for the seeds and in line with previously reported $\mathrm{P}$ forms in other plant materials such as crop residues, leaves, and flowers (Makarov, Haumaier, and Zech 2002; Makarov et al. 2005; Bünemann et al. 2008; Noack et al. 2012; Noack et al. 2014). Our results showed that the major P species in the seeds were in the organic forms (mainly as phytate). This is in agreement with other studies, which found phytate to be the major storage form of P in seeds (Lott et al. 2000; Noack et al. 2012; White and Veneklaas 2012; Noack et al. 2014). Phytate is reported to be stable under alkaline solutions and is also one of the primary storage forms of $\mathrm{P}$ in seeds up to $90 \%$ of total organic $\mathrm{P}$ (Lott et al. 2000; Turner et al. 2002; Noack et al. 2012).

The results from this study also follow this trend with the exception of fennel seeds, which reported values below $50 \%$ of total extractable P. The synthesis and accumulation of phytate in seeds has been reported to occur in cells where it is stored, mostly in form of large electron-dense spheres called globoids. Previous studies have reported a relationship between the size and number of these globoids with the $(\mathrm{Mg}+\mathrm{Ca}) / \mathrm{K}$ ratio of mature seeds (Lott et al. 2000). Thus, the higher the $(\mathrm{Mg}+\mathrm{Ca}) / \mathrm{K}$ ratio, the larger and more frequent the globoids occur in the seeds. Our results showed fennel seed had the lowest $(\mathrm{Mg}+\mathrm{Ca}) / \mathrm{K}$ ratio (Table 1), most likely due to the low phytate concentration compared to the other seeds. On the other hand, flax, mustard, poppy, and sesame seeds all had ratios greater than 0.80 , which was reflected by their high (greater than 63\%) phytate concentration, suggesting the formation of larger and more 
frequent globoids in these seeds. These results also explain why fennel seeds contained the highest concentration of $\mathrm{K}$ compared to other seeds. Studies have shown that during seed formation, as the concentration of $\mathrm{K}$ increases, the concentration of polyvalent cations such as $\mathrm{Ca}$ decreases in the seed (Ogawa, Kunisuke, and Zenzaburo 1979). This also explains why the K concentration was the highest in all seeds (Table 1).

The other organic $\mathrm{P}$ species, whose chemical shifts resonated in the monoester region, most likely were degradation products of labile organic P compounds (mainly diesters), such as phospholipids and nucleic material. The absence of stable diesters such as DNA in most ${ }^{31} \mathrm{P}$ NMR seed spectra was likely as a result of their low concentrations and signal-to-noise ratios. However, the low concentration or complete absence of these P diesters in the seed extracts was likely governed by their relative instability in the $\mathrm{NaOH}$-EDTA alkaline solution. Thus, we can only suggest that the glycerophosphates and mononucleotides in our seed extracts, are either present in the seeds or are degradation products of alkaline hydrolysis (Turner et al. 2003; Doolette, Smernik, and Dougherty 2009). This usually occurs during the extraction and redissolution required for ${ }^{31} \mathrm{P}$ NMR, thereby leading to an underestimation of diesters and overestimation of monoesters. However, previous studies by Doolette, Smernik, and Dougherty (2009) on the identification of phospholipid degradation products, showed that degradation in $\mathrm{NaOH}-\mathrm{EDTA}$ to give glycerophosphates (mainly as $\alpha$ - and $\beta$-gycerophosphate). This study shows that the low concentrations of glycerophosphates (sum of $\alpha$ - and $\beta$-gycerophosphate) found in sesame, mustard, and poppy were unexpected, considering that they are commonly considered as oil seeds. Noack et al. (2012) also reported similar low glycerophosphate values in canola seed extracts, which they attributed to the $\mathrm{NaOH}-\mathrm{EDTA}$ extraction. During the $\mathrm{NaOH}-$ EDTA extraction, the oil seed extracts form two layers due to high lipid content and low aqueous 
solubility of the phospholipids; the denser water layer which is used for the ${ }^{31} \mathrm{P}$ NMR determination would likely contain little phospholipid, resulting in an underestimation of the diester concentration in the seed extracts. Similar behavior was observed in this study with sesame, poppy, and mustard seeds following extraction with the alkaline solution, redissolution, and centrifugation before ${ }^{31} \mathrm{P}$ NMR.

The inorganic $\mathrm{P}$ forms in the seeds were also in agreement with those reported in other studies on plant materials (Makarov, Haumaier, and Zech 2002; Bünemann et al. 2008; Noack et al. 2012; Noack et al. 2014). The concentration of orthophosphate in the seeds was less than $30 \%$ for all seeds except for fennel. This high percentage of $\mathrm{P}$ as orthophosphate in fennel means that almost half of the $\mathrm{P}$ contained in this seed was in its available form and thus remobilized for the development of new seedlings, in contrast with the low values found in mustard and sesame seeds.

The other inorganic $\mathrm{P}$ form detected only in fennel and poppy were the pyrophosphates, which are the smallest group of inorganic condensed polyphosphates, found in nature, and are highly soluble in soil solution where they are readily available for plant uptake. They have been reported in plant tissues such as stems (Noack et al. 2012) but to the best of the authors' knowledge, never in seeds. They are usually formed by the dehydration of orthophosphate at elevated temperatures or the enzymatic condensation of orthophosphate by select kinases (Kornberg 2008). Although the factors regulating their synthesis, storage, and removal are yet to be fully understood (Kornberg 1999), they perform numerous functions depending on the type of species and cellular compartment. Their main functions in plants include storage of $\mathrm{P}$ when inorganic $\mathrm{P}$ is in excess and may be involved in osmotic pressure regulation (Kornberg 1999). This property may be applicable for fennel and poppy seeds as they had higher orthophosphate 
concentrations. In addition, pyrophosphate may act as a sink or strong chelator of metals ions such as $\mathrm{Ca}^{2+}, \mathrm{Mn}^{2+}$, and $\mathrm{Mg}^{2+}$ (Kornberg 1999). This chelating ability is as a result of their high binding capacity, which is supported by the mineral results. Table 1 shows that fennel and poppy seeds contained higher concentration of these metals compared to the other seeds, where pyrophosphates were not detected or quantifiable.

The relationship between the total extractable inorganic $\mathrm{P}$ determined by ${ }^{31} \mathrm{P}$ NMR and chemical characterization (water extraction) with ICP-AES analysis for inorganic water extractable $\mathrm{P}$ was also highlighted with both methods giving comparable values for most seeds. However, the higher values obtained from the water extraction may be explained because water extractable P usually contains species like orthophosphate, soluble inorganic condensed P forms such as poly- and pyrophosphates, and organic $\mathrm{P}$. The difference in the results may be the result of enzyme-induced hydrolysis, encouraged in the neutral $\mathrm{pH}$ of the water extracts of labile organic P species, likely monoesters and diesters, into orthophosphate during the extraction. However, the alkaline $\mathrm{pH}$ of the $\mathrm{NaOH}$ - EDTA extractant, normally higher than 13 , deactivated these enzymes in seeds (Noack et al. 2014). This process may lead to an increase in water extractable inorganic P concentrations in the seed extracts.

\section{CONCLUSIONS}

Cumin, fennel, flax, mustard, poppy, and sesame seeds were analyzed for P species using chemical characterization and ${ }^{31} \mathrm{P}$ NMR spectroscopy. The results demonstrated that $\mathrm{P}$ was mainly present in organic forms such as orthophosphate monoesters (phytate, glycerophosphates and mononucleotides) and orthophosphate diesters. Only two samples, fennel and poppy seeds contained pyrophosphate, but in small concentrations $(<1 \%)$, while phosphonates and polyphosphates were not detected in any seeds. Phytate was the most dominant $\mathrm{P}$ form in all with 
the exception of fennel seeds, which contained the lowest phytate concentration but the highest orthophosphate and glycerophosphate concentrations. Similarly, mustard seeds, which had the highest phytate concentration, also contained the lowest glycerophosphate concentration and the second to lowest orthophosphate concentration. These results suggest that not all the phosphorus transferred from the plants' leaves, roots, and flowers to the seeds during maturation is converted to phytate (organic P) but may also be stored as orthophosphate (inorganic P form).

The results also suggest that the fennel seeds contained smaller, less frequent phytate containing globoids compared to the other species. This point was reflected in its high $\mathrm{K}$ and orthophosphate concentration compared to the other seeds. These results suggest that during seed formation, $\mathrm{K}$ accumulation is accompanied by a decline in Ca concentration, which was reflected in the seed mineral concentrations.

\section{Acknowledgments}

The authors (AS and VT) would like to acknowledge the Welsh government ERDF projects BEACON and WISE Network (United Kingdom) for their financial support. VE would like to acknowledge the Delta State Government of Nigeria for his scholarship. Jonathan Roberts is acknowledged for the $\mathrm{C}$ and $\mathrm{N}$ analysis.

\section{References}

Batten, G. D. 1992. A review of phosphorus efficiency in wheat. Plant Soil 146:163-68. doi:10.1007/bf00012009

Batten, G. D., and M. A. Khan. 1987. Uptake and utilisation of phosphorus and nitrogen by bread wheats grown under natural rainfall. Australian Journal of Experimental Agriculture 27:405-10. doi:10.1071/ea9870405

Bolland, M. D. A., and M. J. Baker 1988. High phosphorus concentrations in seed of wheat and annual medic are related to higher rates of dry matter production of seedlings and plants. Australian Journal of Experimental Agriculture 28:765-70. doi:10.1071/ea9880765

Bünemann, E. K., R. J. Smernik, A. L. Doolette, P. Marschner, R. Stonor, S. A. Wakelin, and A. M. McNeill. 2008. Forms of phosphorus in bacteria and fungi isolated from two 
Australian soils. Soil Biology and Biochemistry 40:1908-15. doi:10.1016/j.soilbio.2008.03.017

Cade-Menun, B. J., and C. M. Preston. 1996. A comparison of soil extraction procedures for 31P NMR spectroscopy. Soil Science 161:770-85. doi:10.1097/00010694-199611000-00006

Coruzzi, G., and D. R. Bush. 2001. Nitrogen and carbon nutrient and metabolite signaling in plants. Plant Physiology 125:61-64. doi:10.1104/pp.125.1.61

Damon, P. M., B. Bowden, T. Rose, and Z. Rengel. 2014. Crop residue contributions to phosphorus pools in agricultural soils: A review. Soil Biology and Biochemistry 74:12737. doi:10.1016/j.soilbio.2014.03.003

Dionisio, G., P. B. Holm, and H. Brinch-Pedersen. 2007. Wheat (Triticum aestivum L.) and barley (Hordeum vulgare L.) multiple inositol polyphosphate phosphatases (MINPPs) are phytases expressed during grain filling and germination. Plant Biotechnology Journal 5:325-38. doi:10.1111/j.1467-7652.2007.00244.x

Dionisio, G., C. K. Madsen, P. B. Holm, K. G. Welinder, M. Jørgensen, E. Stoger, E. Arcalis, and H. Brinch-Pedersen. 2011. Cloning and characterization of purple acid phosphatase phytases from wheat, barley, maize and rice. Plant Physiology 156:1087-100. doi:10.1104/pp.110.164756

Doolette, A. L., R. J. Smernik, and W. J. Dougherty. 2009. Spiking improved solution phosphorus-31 nuclear magnetic resonance identification of soil phosphorus compounds. Soil Science Society of America Journal 73 (3):919-27. doi:10.2136/sssaj2008.0192

Doolette, A. L., R. J. Smernik, and W. J. Dougherty. 2011. A quantitative assessment of phosphorus forms in some Australian soils. Soil Research 49:152-65. doi:10.1071/sr10092

Güsewell, S. 2004. N: P ratios in terrestrial plants: Variation and functional significance. New Phytologist 164:243-66. doi:10.1111/j.1469-8137.2004.01192.x

Kornberg, A. 1999. Inorganic polyphosphate: A molecule of many functions. In Inorganic polyphosphates, 1-18. Springer Berlin Heidelberg.

Kornberg, A. 2008. Abundant microbial inorganic polyphosphate, poly $\mathrm{P}$ kinase are underappreciated. Microbe Magazine 3:119-23. doi:10.1128/microbe.3.119.1

Lott, J. N. A., J. S. Greenwood, and G. D. Batten. 1995. Mechanisms and regulation of mineral nutrient storage during seed development 215-35. New York: Marcel Dekker.

Lott, J. N. A., I. Ockenden, V. Raboy, and G. D. Batten. 2000. Phytic acid and phosphorus in crop seeds and fruits: A global estimate. Seed Science Research 10:11-33.

Makarov, M., L. Haumaier, and W. Zech. 2002. The nature and origins of diester phosphates in soils: A P-31-NMR study. Biology and Fertility of Soils 35:136-46. doi:10.1007/s00374002-0454-8

Makarov, M. I., L. Haumaier, W. Zech, O. E. Marfenina, and L. V. Lysak. 2005. Can 31P NMR spectroscopy be used to indicate the origins of soil organic phosphates? Soil Biology and Biochemistry 37:15-25. doi:10.1016/j.soilbio.2004.07.022

McDowell, R. W., B. Cade-Menun, and I. Stewart. 2007. Organic phosphorus speciation and pedogenesis: Analysis by solution 31P nuclear magnetic resonance spectroscopy. European Journal of Soil Science 58:1348-57. doi:10.1111/j.1365-2389.2007.00933.x

McDowell, R. W., L. M. Condron, I. Stewart, and V. Cave. 2005. Chemical nature and diversity of phosphorus in New Zealand pasture soils using 31P nuclear magnetic resonance spectroscopy and sequential fractionation. Nutrient Cycling in Agroecosystems 72:24154. doi:10.1007/s10705-005-2921-8 
Nadeem, M., A. Mollier, C. Morel, A. Vives, L. Prud'homme, and S. Pellerin. 2011. Maize (Zea mays L.) endogenous seed phosphorus remobilization is not influenced by exogenous phosphorus during germination and early growth stages. Plant and Soil 346:231-44. doi:10.1007/s11104-011-0814-y

Newman, R. H., and K. R. Tate. 1980. Soil phosphorus characterisation by 31P nuclear magnetic resonance. Communications in Soil Science and Plant Analysis 11:835-42. doi:10.1080/00103628009367083

Noack, S. R., M. J. McLaughlin, R. J. Smernik, T. M. McBeath, and R. D. Armstrong. 2012. Crop residue phosphorus: Speciation and potential bio-availability. Plant and Soil 359:375-85. doi:10.1007/s11104-012-1216-5

Noack, S. R., M. J. McLaughlin, R. J. Smernik, T. M. McBeath, and R. D. Armstrong. 2014. Phosphorus speciation in mature wheat and canola plants as affected by phosphorus supply. Plant and Soil 378:125-37. doi:10.1007/s11104-013-2015-3

Oberleas, D., and B. F. Harland. 1981. Phytate content of foods effect on dietary zinc bioavailability. Journal of the American Dietetic Association 79:433-36.

Ogawa, M., T. Kunisuke, and K. Zenzaburo. 1979. Energy-dispersive X-ray analysis of phytin globoids in aleurone particles of developing rice grains. Soil Science and Plant Nutrition 25:437-48. doi:10.1080/00380768.1979.10433184

Pruthi, J. S. 1999. Quality assurance in spices and spice products: Modern methods of analysis. New Dehli: Allied Publisher.

Raboy, V., K. A. Young, J. A. Dorsch, and A. Cook. 2001. Genetics and breeding of seed phosphorus and phytic acid. Journal of Plant Physiology 158:489-97. doi:10.1078/01761617-00361

Reddy, N. R. 2002. Occurrence, distribution, content, and dietary intake of phytate. In Food phytates, ed. N. K. Reddy and S. K. Sathe, 25-51. Boca Raton: CRC Press.

Ros, C., R. W. Bell, and P. F. White. 1997. Effects of seed phosphorus and soil phosphorus application on early growth of rice (Oryza sativa L.) cv. IR66. Soil Science and Plant Nutrition 43:499-509. doi:10.1080/00380768.1997.10414777

Smernik, R. J., and W. J. Dougherty. 2007. Identification of phytate in phosphorus-31 nuclear magnetic resonance spectra: The need for spiking. Soil Science Society of America Journal 71:1045-50. doi:10.2136/sssaj2006.0295

Turner, B. L. 2008. Soil organic phosphorus in tropical forests: An assessment of the NaOHEDTA extraction procedure for quantitative analysis by solution 31P NMR spectroscopy. European Journal of Soil Science 59:453-66. doi:10.1111/j.1365-2389.2007.00994.x

Turner, B. L., B. J. Cade-Menun, L. M. Condron, and S. Newman. 2005. Extraction of soil organic phosphorus. Talanta 66:294-306. doi:10.1016/j.talanta.2004.11.012

Turner, B. L., N. Mahieu, and L. M. Condron. 2003. The phosphorus composition of temperate pasture soils determined by $\mathrm{NaOH}-\mathrm{EDTA}$ extraction and solution 31P NMR spectroscopy. Organic Geochemistry 34:1199-210. doi:10.1016/s0146-6380(03)00061-5

Turner, B. L., M. J. Papházy, P. M. Haygarth, and I. D. McKelvie. 2002. Inositol phosphates in the environment. Philosophical Transactions of the Royal Sociecty of London: $B$ Biological Science 357:449-69. doi:10.1098/rstb.2001.0837

Turner, B. L., and A. E. Richardson. 2004. Identification of-inositol phosphates in soil by solution phosphorus-31 nuclear magnetic resonance spectroscopy. Soil Science Society of America Journal 68:802-08. doi:10.2136/sssaj2004.8020

U.S. EPA United States Environmental Protection Agency. 1994. Method 200.8., USA. 
White, P. J., and M. R. Broadley. 2009. Biofortification of crops with seven mineral elements often lacking in human diets-iron, zinc, copper, calcium, magnesium, selenium and iodine. New Phytologist 182:49-84. doi:10.1111/j.1469-8137.2008.02738.x

White, P. J., and J. P. Hammond. 2008. Phosphorus nutrition of terrestrial plants. In The ecophysiology of plant-phosphorus interactions, ed. P. J. White and J. P. Hammond, 5181. Dordrecht: Springer.

White, P. J., and E. J. Veneklaas. 2012. Nature and nurture: The importance of seed phosphorus content. Plant and Soil 357:1-8. doi:10.1007/s11104-012-1128-4

Zhang, M., M. Nyborg, and W. B. McGill. 1990. Phosphorus concentration in barley (Hordeum vulgare L.) seed: Influence on seedling growth and dry matter production. Plant and Soil 122:79-83. doi:10.1007/bf02851912 
Table 1. Results for $\mathrm{P}$ chemical extractions, total NaOH-EDTA P $\left(\mathrm{g} \mathrm{kg}^{-1}\right)$ extraction, extraction efficiency (\%), elemental analysis ( $\mathrm{mg} \mathrm{kg}^{-1}$ or $\left.\mathrm{kg}^{-1}\right), \mathrm{N}$ to $\mathrm{P}$ ratios, and $(\mathrm{Mg}+\mathrm{Ca}) / \mathrm{K}$ ratios as the average of three replicate measurements \pm the standard deviation.

\begin{tabular}{|c|c|c|c|c|c|c|}
\hline & Cumin & Fennel & Flax & Mustard & Poppy & Sesame \\
\hline \multicolumn{7}{|c|}{ Chemical extraction } \\
\hline Total P in $\mathrm{g} \mathrm{kg}-1$ & $4.5 \pm 0.2$ & $5.0 \pm 0.1$ & $4.7 \pm 0.1$ & $7.1 \pm 0.4$ & $8.3 \pm 0.1$ & $6.9 \pm 0.2$ \\
\hline Inorganic $\mathrm{P}$ in $\mathrm{g}$ kg-1 & $1.1 \pm 0.1$ & $2.3 \pm 0.3$ & $1.4 \pm 0.1$ & $1.9 \pm 0.4$ & $1.9 \pm 0.1$ & $2.8 \pm 0.8$ \\
\hline $\begin{array}{c}\text { Inorganic } \mathrm{P} / \text { Total } \mathrm{P} \\
(\%)\end{array}$ & $23-26$ & $40-52$ & $28-31$ & $21-32$ & $22-23$ & $29-32$ \\
\hline \multicolumn{7}{|c|}{ 31P NMR analysis } \\
\hline $\begin{array}{c}\text { Total NaOH-EDTA P } \\
\text { in } \mathrm{g} \mathrm{kg}-1\end{array}$ & $3.3 \pm 0.3$ & $4.4 \pm 0.1$ & $4.3 \pm 0.3$ & $8.5 \pm 0.2$ & $8.1 \pm 0.6$ & $6.7 \pm 0.6$ \\
\hline $\begin{array}{c}\text { Extraction efficiency } \\
(\%)\end{array}$ & 75 & 88 & 96 & 110 & 97 & 97 \\
\hline $\begin{array}{c}\text { Inorganic } \mathrm{P} / \text { Total } \mathrm{P} \\
(\%)\end{array}$ & & 42 & 23 & 9.3 & 27 & 7.2 \\
\hline \multicolumn{7}{|c|}{ Elemental analysis } \\
\hline $\mathrm{C}(\%)$ & 53 & 47 & 61 & 57 & 59 & 66 \\
\hline $\mathrm{N}(\%)$ & 3.2 & 2.7 & 3.7 & 4.8 & 3.7 & 3.9 \\
\hline $\mathrm{N}: \mathrm{P}$ ratio & 7.1 & 5.5 & 7.9 & 6.8 & 4.5 & 5.7 \\
\hline $\mathrm{Ca}$ in $\mathrm{g} \mathrm{kg}-1$ & $3.9 \pm 0.1$ & $4.2 \pm 0.1$ & $1.7 \pm 0.1$ & $2.67 \pm 0.01$ & $4.5 \pm 0.1$ & $1.0 \pm 0.1$ \\
\hline $\mathrm{K}$ in $\mathrm{g} \mathrm{kg}-1$ & $11.5 \pm 0.2$ & $13.1 \pm 0.3$ & $4.7 \pm 0.1$ & $5.9 \pm 0.7$ & $6.2 \pm 0.5$ & $3.7 \pm 0.2$ \\
\hline $\mathrm{Mg}$ in $\mathrm{g} \mathrm{kg}-1$ & $2.3 \pm 0.1$ & $2.2 \pm 0.1$ & $2.1 \pm 0.1$ & $2.3 \pm 0.1$ & $2.4 \pm 0.1$ & $2.4 \pm 0.1$ \\
\hline $\mathrm{Na}$ in $\mathrm{g} \mathrm{kg}-1$ & $1.7 \pm 0.1$ & $2.7 \pm 0.2$ & $1.4 \pm 0.2$ & $1.1 \pm 0.1$ & $0.8 \pm 0.2$ & $0.7 \pm 0.1$ \\
\hline
\end{tabular}




\begin{tabular}{|c|c|c|c|c|c|c|}
\hline S in g kg-1 & $4.3 \pm 0.1$ & $2.8 \pm 0.7$ & $1.8 \pm 0.3$ & $13.3 \pm 0.2$ & $2.6 \pm 0.7$ & $3.1 \pm 0.9$ \\
\hline $\mathrm{Cu}$ in mg kg-1 & $12 \pm 2$ & $16 \pm 1$ & $14 \pm 1$ & $8 \pm 2$ & $13 \pm 1$ & $20 \pm 3$ \\
\hline Fe in mg kg-1 & $122 \pm 18$ & $112 \pm 16$ & $68 \pm 7$ & $74 \pm 4$ & $135 \pm 10$ & $112 \pm 16$ \\
\hline $\mathrm{Mn}$ in mg kg-1 & $29 \pm 2$ & $41 \pm 3$ & $25 \pm 2$ & $25 \pm 1$ & $107 \pm 4$ & $23 \pm 1$ \\
\hline $\mathrm{Zn}$ in mg kg-1 & $39 \pm 8$ & $42 \pm 10$ & $37 \pm 6$ & $42.4 \pm 0.3$ & $61.3 \pm 0.4$ & $54 \pm 3$ \\
\hline$(\mathrm{Mg}+\mathrm{Ca}) / \mathrm{K}$ ratio & 0.54 & 0.49 & 0.81 & 0.84 & 1.11 & 0.92 \\
\hline
\end{tabular}

Table 2. Percentage of $\mathrm{P}$ species in the $\mathrm{NaOH}-\mathrm{EDTA}$ seed extracts determined by ${ }^{31} \mathrm{P}$ NMR.

${ }^{\mathrm{a}}$ Values in parenthesis are the proportions in percentages of total organic $\mathrm{P}$ as phytate. 


\begin{tabular}{|c|c|c|c|c|c|c|c|c|}
\hline & \multicolumn{2}{|c|}{ Inorganic P } & \multicolumn{3}{c|}{ Organic P } \\
\hline \multicolumn{7}{|c|}{ \% of total NaOH- EDTA extractable P } \\
\hline
\end{tabular}


Figure 1. Solution 31P NMR spectra of plant seed extracts showing orthophosphate, pyrophosphate, and orthophosphate monoesters and diesters. The insets show the orthophosphate monoester region including peaks for (A) phytate, (B) $\alpha$-glycerophosphate, and (C) $\beta$ glycerophosphate.

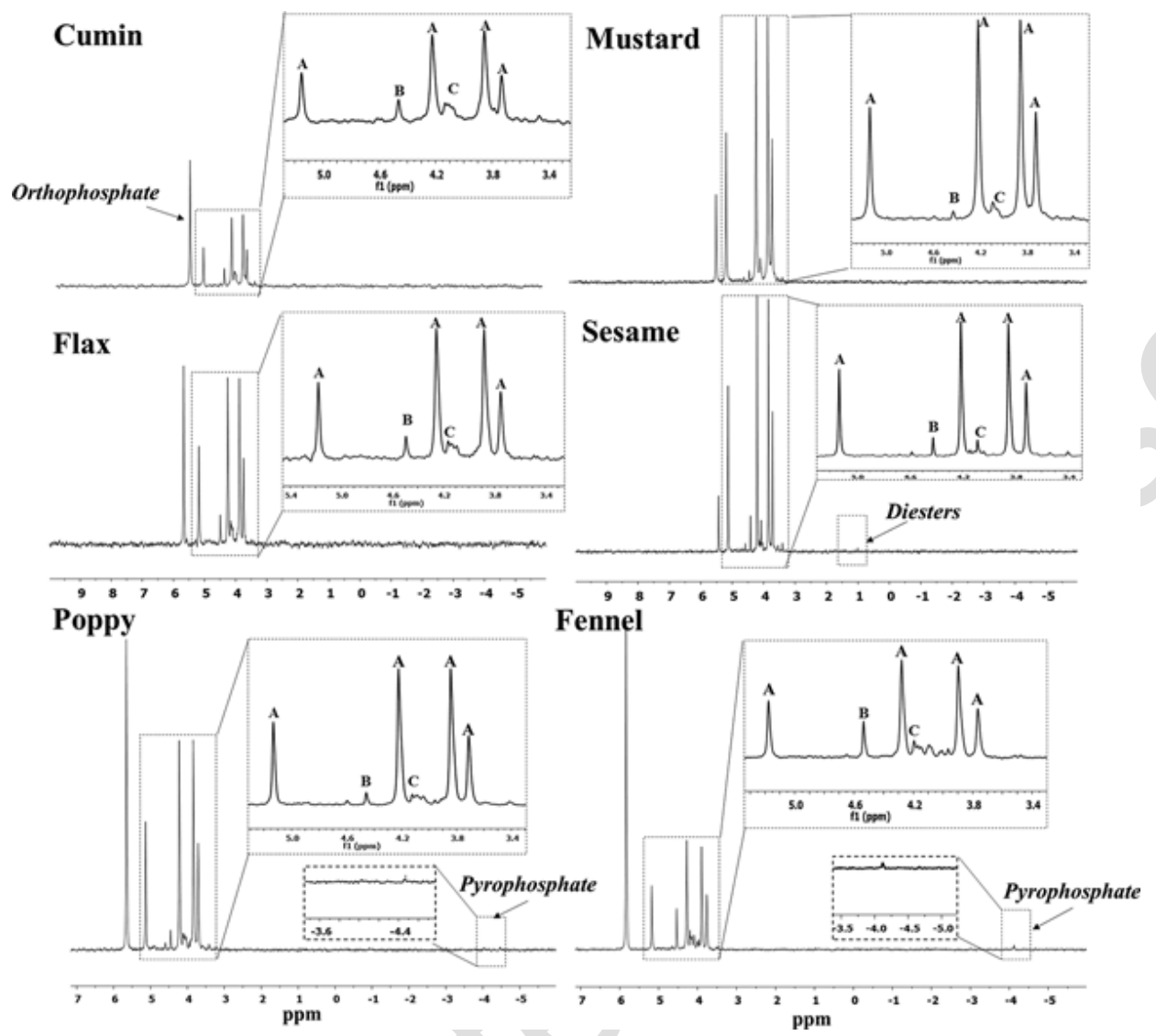


Figure 2. Solution 31P NMR spectra of $\mathrm{NaOH}$-EDTA fennel seed extracts before and after fortification with a (A) phytate standard and cumin seed extract before and after fortification with 1:1 (B) $\alpha$-glycerophosphate and (C) $\beta$-glycerophosphate standards.
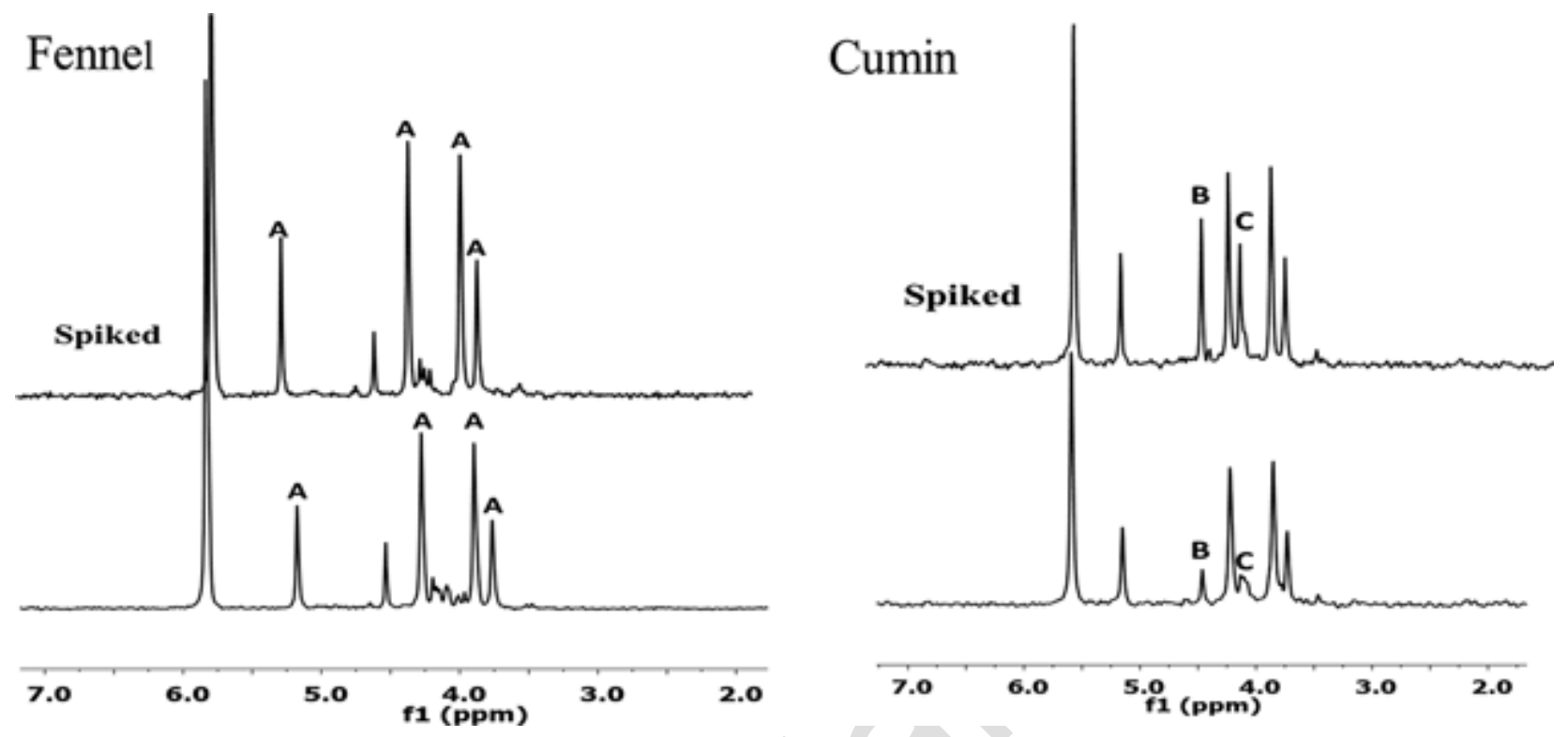
Figure 3. Percent composition of the primary inorganc and organic $P$ species or groups in each $\mathrm{NaOH}-\mathrm{EDTA}$ seed extract by 31P NMR that include orthophosphate, pyrophosphate, phytate, glycerophoshates ( $\alpha$ - and $\beta$ - glycerophosphate), and other monoesters and diesters.

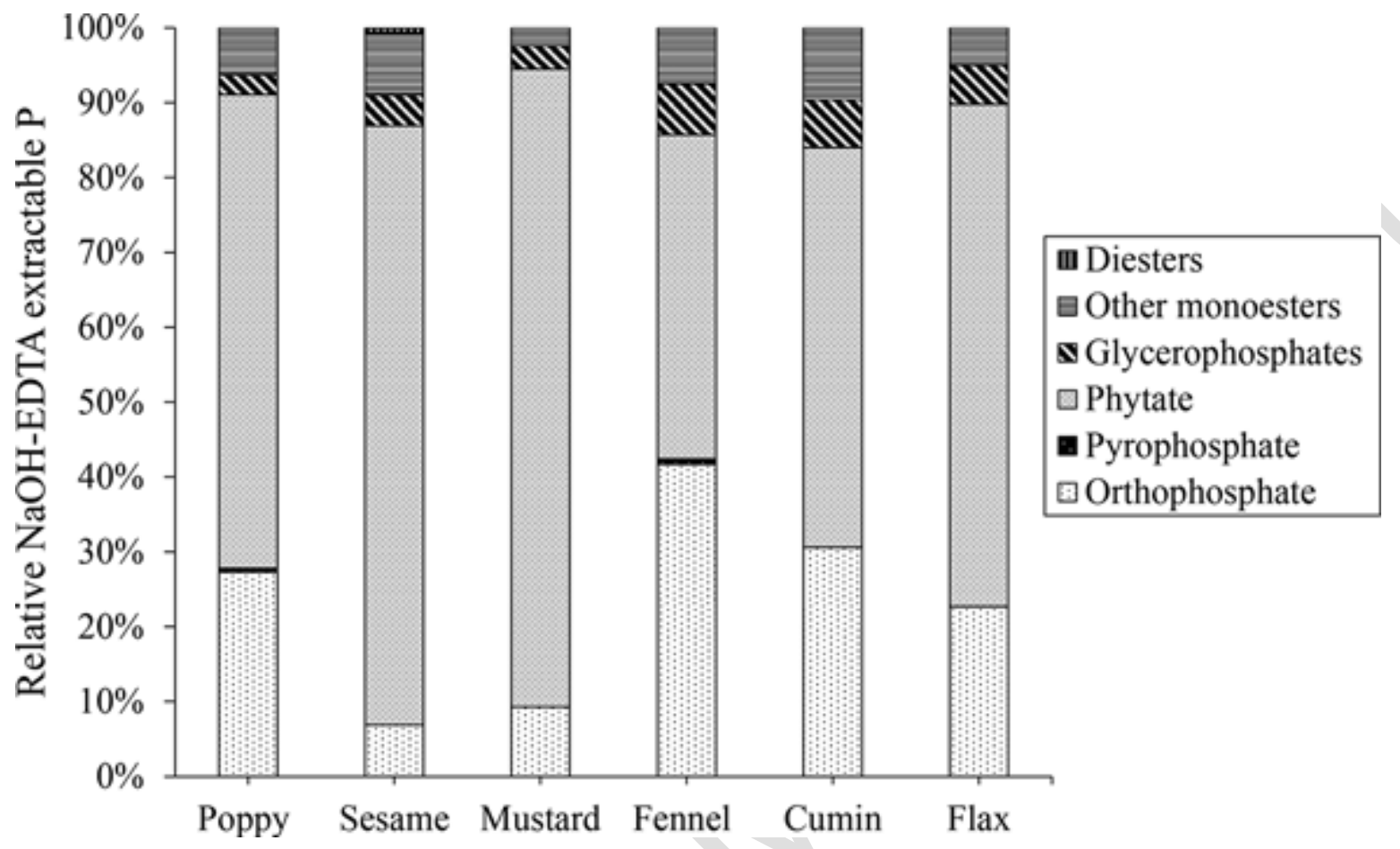

